\title{
Nursing Students' and Educators' Perception toward Nursing Students' Rights and Its relation to Nursing Students' Satisfaction
}

\section{Naima Ali Gouda Ahmed ${ }^{1}$, Reda Abd Elfatah Abo Gad ${ }^{2}$ and Ebtesam Saeed Ahmed Abd- Elrhaman $^{3}$}

(1)Specialist Nurse at Benha University Hospital (B.Sc. Nursing 2013, Benha University) (2)Professor of Nursing Administration, Faculty of Nursing, Tanta University (3)Assistant professor of Nursing Administration, Faculty of Nursing, Benha University

\section{Abstract}

Background: Students' rights has become an important part of modern education due to when the nursing students know their rights and reach it, they experience high satisfaction as there is almost universal agreement regarding the importance of student rights across the educational system. The study aimed to assess nursing students' and educators' perception toward nursing students' rights and its relation to nursing students' satisfaction. Study design: Descriptive correlational design was utilized to conduct this study. Study setting: The study was conducted at the Faculty of Nursing, Benha University. Subjects: Included simple random sample of undergraduate nursing students' from all four academic years 332 out from 1962 who are enrolled at academic year 2019/2020 and available nursing educators' 125 out from 173 at the above mentioned study setting. Tools: Two tools were used for data collection: (I) Nursing students' rights questionnaire and (II) Nursing students' Satisfaction Scale (NSSS). Results: Showed that the majority $(78.9 \%$ \& 95.2\%) of studied nursing students' and educators' had high perceived level toward nursing students' rights respectively. Also, nearly half (48.8\%) of studied nursing students' had high satisfaction level. Conclusion: The study concluded that there was positive statistical significant correlation between total perception of nursing students' and educators' toward nursing student rights and total nursing students' satisfaction .Recommendation: Disseminating this created bill of rights and at all faculties in Benha Universities, also posted students' rights in sites accessible to all students and publishing them on faculty websites and educators use technology effectively and work collaboratively with each other.

Key words: Nursing educators, Nursing students rights and satisfaction.

\section{Introduction}

In era of revolutions and globalization, students are aware of many social topics that affect them and their faculty. Students' rights are the backbone of any university. It is essential that students' rights and duties are actively applied by all concerned (Lindeman, 2018).

A student nurse is a student in a postsecondary educational program that leads to certification and licensing to practice nursing, usually as part of a program administered by a nursing faculty. Nursing student is associated with fundamental rights which intended to maintain the integrity of the nursing education institutions, also there is almost universal agreement regarding the importance of student rights across the educational system (Saravi, Navidian and Yaghoubinia, 2015).

Nursing students as a member of the university community, they willfully consent 
to policy and procedures which out lined in the mission of the university to fulfill student rights' and responsibilities. Any university strives to preserve the rights and dignity of students (Trinity University, 2018).

Student rights are considered fundamental to civilization for they are regarded as established pillar of society and culture. The rights which protect the students; the level of rights accorded to students whether legally or by convention vary considerably around the world (Gershofz and Font, 2016).

\section{According to (The American} University in Cairo, 2012; Princeton University, 2015) stated that student rights is applied to all students either primary, secondary and in any faculty which include public awareness, freedom of expression and communication, freedom of disciplinary action without due process, freedom from discrimination, right to exercise liberty to discuss, inquire, right to confidentiality (privacy), freedom in classroom furthermore.

(International Council of Nurses, 2017; Mayers, 2017) stated that nursing student rights that associated to nursing student and students of scientific universities which include management, laboratory, library, relation between nursing educators and students, educational competence of teachers and educators, rights to be evaluated fairly, selection of training places outside (hospital) and textbooks.

The student bill of rights was created to help student's feel more confident in educational system; the bill of right assures that the educational system is fair and works to meet students' needs, gives student's away to address any problems to take an active role in educational process, in addition the students' rights make a focus on importance of strong relationship between student and their educational places (Wilkes University, 2015).

Nurse educators are registered nurses (RNS) who have obtained advanced nursing degrees that allow them to teach nursing curriculum at colleges and universities, teaching and helping to train the future nurses of the world. (Happell, 2020). Nursing students' perception and opinion is considered as a necessary factor to evaluate quality in universities. All nursing educators team are currently working on ways to improve the quality of their educational provision and increase the satisfaction of their students Chen and Lo, 2018). According to (Chen, Farmer, Barber and Waymam, 2012) who develop nursing student satisfaction scale to measure their satisfaction which include three dimension related to professional social interaction, curriculum, nursing programme and learning environment.

Students' satisfaction as a short term attitude, resulting from an evaluation of a students' educational experiences, services and facilities It is a positive antecedent of student loyalty and outcome of an educational (Garcl and Aracil, 2019). In a competitive environment in which organizations compete with each other to attract customers, their satisfaction is a key element to succeed and an important objective of each organization is to achieve success because it leads to profitability and customers' trust to the organization (Hakim, 2014).

Therefore, evaluating satisfaction concerning the field of study in the college is considered among fundamental subjects of the college and a significant part of its activities in the area of organizational procedure and behavior. On the other hand, since interest in and satisfaction about the field of study is one 
of the most important factors in the students' education and success (Borjian et al., 2019).

\section{Significance of study:}

Nursing educators' perception regarding nursing students' rights are one of the most important factors for the students' success and satisfaction and should be in the top priority of educational planning (Hakim, 2014).

In a competitive environment in which educational institutions compete with each other to attract students, it is vital for university management to prioritize the creation of an educational environment which would increase students' satisfaction (Mthimunye and Danial, 2019).So, students' satisfaction is an important and crucial for each universities because it leads to profitability, success and nursing students' trust to the educational institutions, but in the case of dissatisfaction, inexperience act as a negative propaganda against the institution (Souza, Karkada, Parahoo and et al., 2016).

Educational services in the faculty must provide a foundation for understanding and respecting students' rights, as students' rights are the key for the maintenance and survival of faculties (Lanier, 2018). From the investigator point of view, if the education institutions provide all rights for student, the students become well mature in their thinking, personality and judgment on things which reflect on their satisfaction, and after graduation nursing students will become effective and able to take a proper decision in difference situations, good leader, good decision maker and give the proper rights to proper persons especially patients' rights on direct and indirect care. So this study will be conduct to assess nursing students' and educators' perception toward nursing students' rights and it' relation to nursing students' satisfaction.

\section{Aim of the study}

The aim of this study is to assess nursing students' and educators' perception toward nursing students' rights and its relation to nursing students' satisfaction.

\section{Research Questions:}

- What are the perception levels of nursing students about their rights?

- What are the perception levels of nursing educators about nursing students' rights?

- What are the levels of nursing students' satisfaction?

- Is there a relation between the perception of nursing students and educators toward nursing students' rights and nursing students' satisfaction?

\section{Subjects and method}

\section{I) Technical design:}

The technical design included a description of the study design, study setting, subjects, methods, as well as tools of data collection.

\section{Study design:}

A descriptive correctional design was utilized to conduct this study.

\section{Study setting:}

The current study was conducted at the Faculty of Nursing Benha University, which was established in 1992 and accredited on 25/8/2014 by the National Authority for Quality Assurance and Accreditation of Education (NAQAAE) and the fourth accredited Nursing Faculty between nursing faculties in Egypt. It composed of four floors and there are six scientific departments in the Faculty including; Medical and surgical 
nursing, Maternal and newborn health nursing, Pediatric nursing, Psychiatric and mental health nursing, Community health nursing and Nursing administration department. Also, it included: Quality assurance unit, information technology unit, strategic planning unit, unit of measurement and evaluation, research and scientific publishing unit, crisis and disaster unit, graduates unit, public services center, community service unit, and psychological counseling unit.

\section{Study subjects:}

The subjects of the present study included two groups:

Group (1): Simple random sample of undergraduate nursing students' from all four academic years 332 out from 1962 who are enrolled at academic year 2019/2020 and accepted to participate in the current study and calculated according to the scientific formula:

$n=\frac{N}{1+N(e) 2} \quad$ Where $\mathrm{n}$ is sample size $=332$

$\mathrm{N}$ is total number of nursing students' accept to participate in this study and available at the time of collect data $=1962$

$\mathrm{e}$ is coefficient factor $=0,05 \%$ according to (Yamane,1976).

Group (2): Available nursing educators' 125 out from 173 at the time of study and who accepted to participate in the present study.

\section{Tools of data collection:}

Two tools were used for data collection:

\section{Tool (1): Nursing students' rights questionnaire (Appendix I):}

It consisted of two parts:

Part (1): Included demographic characteristics of the study subjects:
-Nursing students as; age, gender, residence, marital status, academic year, participation in the faculty activities and type of activity.

-Nursing educators as; age, gender, residence, marital status, years of teaching experience and academic degree.

Part (2): Used to assess nursing students' and educators' perception about nursing students' rights. It was developed by investigator after reviewing the related literature (Hajira and Shamsa, 2012; Merriam, 2015; Princeton University, 2015 and Sidel, 2016).It included 95 items grouped under general and specific rights where general rights.

\section{Scoring system:}

Responses of the applicants were measured by using a three point Likert scale ranged from (1-3) as; (3) agree, (2) neutral and (1) disagree. Each subject chosen only one answer after reading and understanding carefully. Finally the scores of each dimension summed up and converted to percent scores. Range of scores from (95-285) and cut point was done at $60 \%=171$ point. Accordingly, levels of nursing students'/educators perception toward nursing student rights was categorized as the following; high perceived level if the percent $\geq 75 \%$ that equal to 241 point, moderate perceived level if the percent from $60-<75 \%$ that equal from 171-< 241 point and low perceived level if the percent $<60 \%$ that equal to < 171 point (Zakaria et al., 2019).

\section{Tool (2): Nursing students' Satisfaction Scale (NSSS) (Appendix II):}

It was adopted from (Chen, Farmer, Barber and Wayman, 2012) to assess the levels of nursing students' satisfaction, and consisted of 25 items divided into three domains. 


\section{Scoring system:}

The studied nursing students' responses were rated by using a three point Likert scale ranged from (1-3) as; (3) always, (2) some times and (1) never. Each studied nursing students' chosen only one answer after reading and understanding carefully. Finally the scores of each domain summed up and converted to percent scores. Range of scores from (25-75) and cut point was done at $60 \%=$ 45 point. So, the levels of academic satisfaction among nursing students' were categorized as the following; high satisfaction level if the percent $\geq 75 \%$ of total score that equal to $\geq 56$ point, moderate satisfaction level if the percent from $60-<75 \%$ that equal from 45- <56point and low satisfaction level if the percent $<60 \%$ of the total score that equal $<45$ point (Watfa, Mohamed and Ahmed, 2019).

\section{Statistical design:}

The collected data organized, tabulated and statistically analyzed using statistical package for social science (SPSS) version 21 for windows, running on IBM compatible computer. Descriptive statistics were applied (e.g frequency, percentage, mean and standard deviation. Test of significance, Chi-square test and independent t-test was used to detect the relation between variables. In addition, correlation coefficient ( $r$ ) test was used to estimate the closeness association between variables. The P-value is the probability that an observed difference is due to chance and not a true difference. A significant level value was considered when $\mathrm{p}$-value $<0.05$ and a highly significant level value was considered when $\mathrm{p}$-value $<0.001$, while $\mathrm{p}$-value $>0.05$ indicates non- significant results.

\section{Results}

Table (1) illustrates that more than half $(53.0 \%)$ of studied nursing were aged more than 20 years old. As far as their gender and residence about three fifth $(56.6 \%$ \& $62.0 \%)$ of studied nursing students' were female and from rural area respectively. Regarding their marital status, the vast majority (92.8\%) of studied nursing students' were unmarried. According to their academic year of education, more than one quarter (28.9\% \& $26.2 \%)$ of studied nursing students' from first and third year respectively, and three quarter $(75 \%)$ of them not participated in the faculty activities.

Table (2) shows that three fifths $(60.0 \%)$ of studied nursing educators' were aged from 30 to 40 years old, and all $(100 \%)$ of them were female. As far as their residence about more than half $(55.2 \%)$ of studied nursing educators' were from urban area and the vast majority $(93.6 \%)$ of them were married and nearly half of them $(52 \% \& 44.8 \%)$ had less than 10 years of teaching experience and worked as lecturer respectively.

Figure (1) indicates that the majority (78.9\% \& 95.2\%) of studied nursing students' and educators' had high perceived level while, the lowest percentage $(9.1 \% \& 0.8 \%)$ of them had low perceived level toward nursing students' rights respectively. Also, nursing educators' reported higher perception level as compared to nursing students.

Figure (2) indicates that nearly half (48.8 $\%)$ of studied nursing students' had high satisfaction level while about one fifth $(20.5 \%)$ of them had low satisfaction level among studied nursing students'.

table (3) shows that there was positive statistical significant correlation between total perception of nursing students' and educators' toward nursing student rights and total nursing students satisfaction $(\mathrm{p}<0.05)$. 
Table (1): Distribution of the studied nursing students' regarding their demographic characteristics $(n=332)$

\begin{tabular}{|c|c|c|}
\hline Demographic characteristics & No & $\%$ \\
\hline \multicolumn{3}{|l|}{ Age in years } \\
\hline$<20$ & 156 & 47.0 \\
\hline$>20$ & 176 & 53.0 \\
\hline Mean $\square$ SD & \multicolumn{2}{|c|}{$\mathbf{2 0 . 5 7} \square \mathbf{1 . 2 1 8}$} \\
\hline \multicolumn{3}{|l|}{ Gender } \\
\hline Male & 144 & 43.4 \\
\hline Female & 188 & 56.6 \\
\hline \multicolumn{3}{|l|}{ Residence } \\
\hline Rural & 206 & 62.0 \\
\hline Urban & 126 & 38.0 \\
\hline \multicolumn{3}{|l|}{ Marital status } \\
\hline Married & 24 & 7.2 \\
\hline Unmarried & 308 & 92.8 \\
\hline \multicolumn{3}{|l|}{ Academic year } \\
\hline First & 96 & 28.9 \\
\hline Second & 74 & 22.3 \\
\hline Third & 87 & 26.2 \\
\hline Fourth & 75 & 22.6 \\
\hline \multicolumn{3}{|c|}{ Participation in the faculty activities } \\
\hline Yes & 83 & 25.0 \\
\hline No & 249 & 75.0 \\
\hline
\end{tabular}


Table (2): Distribution of the studied nursing educators' regarding their demographic characteristics $(n=125)$

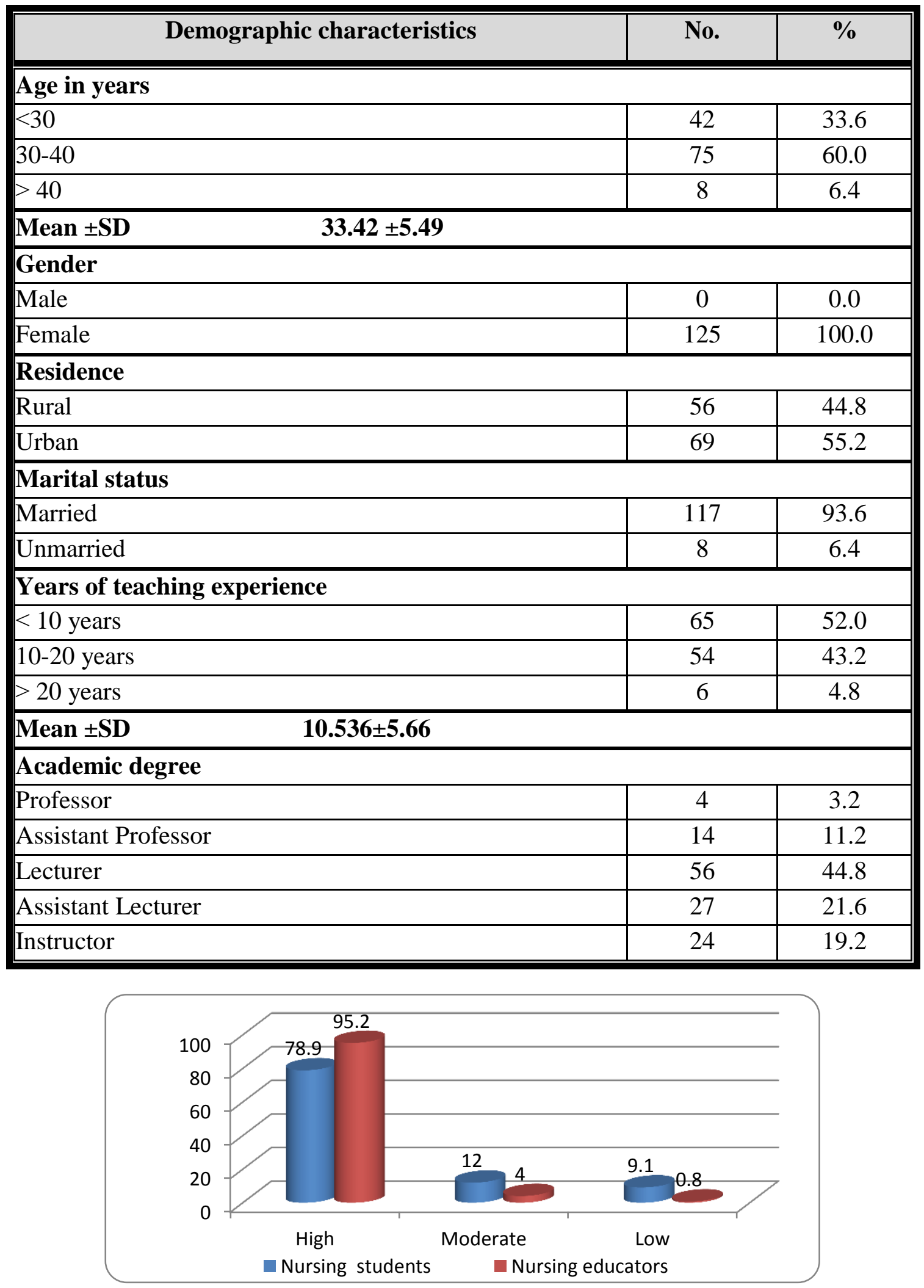

Figure (1): Total perception levels toward nursing students' rights among nursing students' and educators' 


\section{Nursing Students' and Educators' Perception toward Nursing Students' Rights}

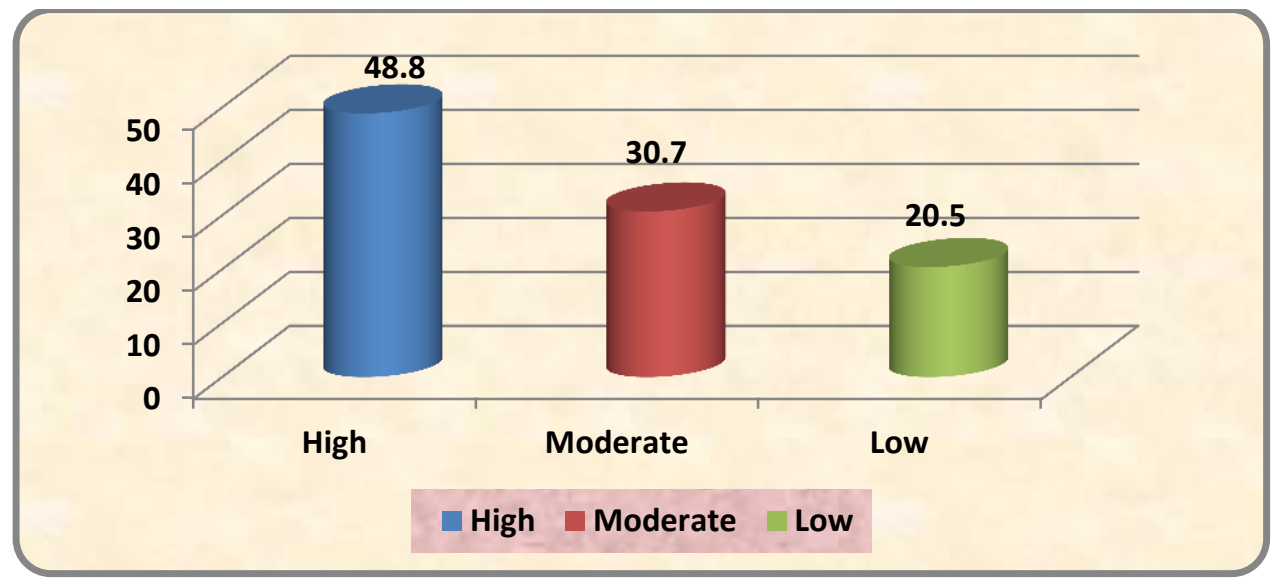

Figure (2): Total levels of satisfaction among studied nursing students

Table (3): Correlation between total perception of nursing students' and educators' toward nursing student rights and total nursing students' satisfaction $(n=457)$

\begin{tabular}{|c|c|c|}
\hline \multirow[t]{2}{*}{ Variables } & \multicolumn{2}{|c|}{ Total nursing students` satisfaction } \\
\hline & $\mathbf{R}$ & $P$ value \\
\hline $\begin{array}{l}\text { Total nursing } \\
\text { perception about their rights }\end{array}$ & 0.622 & $0.027 *$ \\
\hline $\begin{array}{lr}\text { Total nursing } & \text { educators` } \\
\text { perception about } & \text { nursing } \\
\text { students` rights } & \end{array}$ & 0.463 & $0.047 *$ \\
\hline
\end{tabular}

*A statistical significant correlation $(\mathbf{P} \leq \mathbf{0 . 0 5})$

\section{Discussion:}

Nursing students' and educators' perception toward nursing students rights

This part of discussion covered the answer of the first and second research questions; what are the perception levels of nursing students about their rights?

What are the perception levels of nursing educators about nursing students' rights?

Concerning total perception levels toward nursing students' rights among nursing students' and educators'; the finding of the current study indicated that the majority of studied nursing students' and educators' had high perceived level toward nursing student right, also nursing educators' reported higher perception level as compared to nursing students.

From the investigator's point of view this might be because the faculty of nursing are currently within the scope of the quality of education and the majority of nursing students' and educators' were more conscious, participated, engaged and involved in the activities for quality assurance unit among them is the dissemination of quality culture that embodies the nursing students' rights that lead to nursing student and educators positive perception for all things around students' rights.

The result of the present study was supported by Mohammed, (2012) that conducted a study in Egypt to assess nursing 
students' rights as perceived by nursing student and teacher and reported that the nursing student and teacher had high level of nursing student rights and nursing educators' reported had more perception level than nursing students.

Part III: Distribution of nursing students' satisfaction among studied nursing students'

This part answers the third research question; what are the levels of nursing students' satisfaction?

Regarding total levels of satisfaction among studied nursing students, the result of the current study indicated that nearly half of studied nursing students' had high satisfaction level. From the investigator's point of view this might be because the educator is given sufficient guidance with knowledge and experience to students. Also, the program designed to facilitate learning and encourage students for team work and relation among them.

This finding was in agreement with Weerasinghe and Dedunu, (2017) who conducted study on University facilities and student satisfaction in selected state universities in sirilanka and matched that the most of student were high satisfied. Otherwise this result disagreement with Hakim, (2014) who studied nursing students' satisfaction about their field of study, University of Medical Sciences, Iran, and reported that most students had little satisfaction concerning their field of study and recommended that, it is necessary to make an attempt for continuous development of quality services. As well as, this finding was disagreed with Navarro, Iglesias and Torres, (2015) who conducted study of anew management element for universities: Satisfaction with the offered courses in Armenian and confirmed that there was low student satisfaction levels.

\section{Part IV: Correlation between total perception of nursing students' and educators' toward nursing student rights and total nursing students' satisfaction}

This part answers the fourth research question: Is there a relation between the perception of nursing students and educators toward nursing students' rights and nursing students' satisfaction?

Regarding correlation between total perception of nursing students' and educators' toward nursing student rights score and total nursing students satisfaction, The result of current study revealed that there was statistical significant positive correlation between total perception of nursing students' and educators' toward nursing student rights score and total nursing students satisfaction. This means that when students know their rights and reach it their satisfaction will increase. From the investigator point of view that most of the nursing students' know their rights which are currently within the scope of the quality of education that the nursing students' were more conscious, the majority of the participants were young aged students who had positive perception for all issues around them that makes them think positively. Also, student satisfaction is a part of their educational success and commitment of student rights as privacy, freedom of expression, and fair in evaluation and good relation between educators, administration and student will achieve their satisfaction.

Similarly, Mostafa and Shazly, (2015) who conducted study at Helwan University about creating bill of student rights and responsibility that revealed a high is statistical significant positive correlation between students' scores of agreement upon rights and 
responsibilities as reported by the students' are interdependent on each other. This is supported by the Lipson, (2010) who reported in his study the University of Miami in Chicago about Cite Right: A quick guide to citation styles who found that a positive correlation between students' rights and responsibilities. Also in similar Mohamed, (2012) as reported that there was statistically relation between perception of nursing students' and teachers' toward nursing' student rights score.

\section{Conclusion}

Based on the current study findings, it can be concluded that, the majority of studied nursing students' and educators' had high perceived level about nursing students rights. And nursing educators' reported higher perception level as compared to nursing students.

Also, nearly half of studied nursing students' had high satisfaction level. Moreover, there was positive statistical significant correlation between total perception of nursing students' and educators' toward nursing student rights and total nursing students' satisfaction. So, when perception of nursing students' and educators' toward nursing student rights increased, the nursing students satisfaction increased and that reflect the importance of the perception of nursing students and nursing educators toward nursing student rights.

\section{Recommendation}

In the light of the finding reached from the present study, the following points are recommended:

\section{For faculty administrator}

1- Enhancing student protection inside the faculty and providing necessary for safety environment to nursing students.
2- Disseminating this created bill of rights and responsibilities in all faculties at Benha University.

3- The student's bill rights should be posted in sites accessible to all students in all faculties.

4- Providing assessment sheet to nursing student to represent student opinion about faculty policy and represent student opinion in faculty administration by using questionnaire for knowing needs and problems associated with the faculty.

5- Explaining to students their rights in appealing or objecting to any disciplinary ruling issued against them.

6- Providing library with required references in various felids beside the nursing books to enhance nursing students' information in all fields.

7- Providing financial and emotional support to students in critical situations without severity or embarrassment to increase their self-confidence.

8- $\quad$ Enriching classroom environment by comfortable and classroom must be have wide space and equipment in the nursing laboratory must be up to date and suitable to technology development.

\section{For nursing educators:}

1- Providing an objective assessment to nursing students without discrimination.

2- Maintaining confidentiality of any penalties issued against the students.

3- Providing general overview about the course specification to nursing students at the beginning of the courses.

4- Using modern teaching methods in training such as Sims man, Sims baby.

5- Providing students opportunities for solving problems and share in making decisions to increase their responsibility. 
6- Using technology effectively and work collaboratively with each other in their teaching.

\section{For nursing Students:}

1- Discussing the various dimensions of perception of students' rights that reflect on satisfaction with educators and faculty administrators.

2- Attending seminar about students' rights to know it and best utilization to it.

3- Sharing in problem solving and decision making for improving their personality in working in the future.

\section{For further research}

1- Reapplication of the study on the larger probability sample at different nursing faculties and universities in an effort to more fully understand and highly recommended to achieve generalizable results.

2- Conduct study to explore relation between perception of nursing student rights and their professional autonomy.

3- Conduct study to examine factors affecting nursing students' satisfaction.

\section{References}

Borjian Borujeni, A., Reisi, S., Borjian, S. and Mansuri, S. (2019). The Survey of satisfaction of nursing educated about their field of study. Borujen Scientific Journal of Hamadan Nursing and Midwifery Faculty, 18 (2): PP. 50-4.

Hakim, A. (2014). Nursing students' satisfaction about their field of study, Nursing Department, Ahvaz Jundishapur University of Medical Sciences, Ahvaz, Iran, April 2014, 2(2):PP. 23-45.

Happell, B. (2020). Clinical experience in mental health nursing: Determining satisfaction and the influential factors. Nurse Education Today. 28(7): 849-855.
Hajira, B., and Shamsa, A. (2012). Reflective practices and teacher educators: An Exploratory Study. International J. Soc; PP: 90-95.

Lindeman, C. (2018). "A vision for nursing education." Creative

Nursing (January/February 2018): PP. 2-5.

Lipson, C. (2010). Cite Right: A quick guide to citation styles - MLA, APA, Chicago, the sciences, professions, and more. Chicago: University of Chicago Press. Library location: Humanities and Social Sciences.

Lanier, J., (2018). Redefining the role of the teacher it's a multifaceted profession; Edutopia, George Lucas Educational Foundation 1997, PP: 232-255.

Mayers, P. (2017): Introducing student rights and health education into a nursing curriculum. Curationis. 2017 Dec; 3(4): PP. 53-60.

Mohammed, R. (2012). Nursing student rights as perceived by nursing student and teacher, Egypt Department of Nursing Administration, Faculty of Nursing, Ain shams University.

Mostafa, G. and Shazly, M. (2015). Creating bill of student rights and resposabilites at Helwan universities, Journal of education and practice Vol. 6, No 2.

Mthimunye, T. and Daniels, M. (2019). Student nurses' perceptions of their educational environment at a school of nursing in Western Cape Province, South Africa: A cross-sectional study, 42(1): PP. 125-130.

Merriam- Webseter (2015). Student right and satisfaction; from http://WWW.meriamwebseter.com/dictionary/student .Accessed at 3 march 2019. 
Saravi, F., Navidian, A. and Yaghoubinia, F. (2015). Nursing students' views of nursing education quality: a qualitative study. Glob J Health Sci; 7(2), PP: 351-359.

Souza, D., Karkada, N., Parahoo, K., and Venkatesaperumal, R. (2016). Perception of and satisfaction with the clinical learning environment among nursing students;33(3), PP:105-125.

The American University in Cairo, (2012). The Students' bill of rights and responsibilities, the student handbook, the university catalogue, and the constitution of the general assembly of students. Academic committee member work group, student union academic committee. http://www.aucegypt.edu.

Watfa, s., Mohamed, s. and Ahmed, E. (2019). Nursing Students and educators perception toward clinical instructional experience at secondary technical school. PP: 41-42.

Wilkes University, (2015). Policy on students' responsibility for being informedhandbook.http://www.wilkes.edu/inc lude/academics/Nursing/undergrad/StudentHa ndbook.http://www.aucegypt.edu/faculty/Doc uments/FacHandbook2012-2013.pdf June 20,2012.

Zakaria, N., Hamzah, N., Yamin, A., Hamidon, I., Ariffin, A. and Rubani, k. (2019). Competency in career management among technical university students. International Journal of Academic Research in Business and Social Sciences, 9 (13): PP. 173-182.

Garcl, A. and Aracil, A. (2019). European graduates' level of satisfaction with higher education. Journal of Higher Education, 57(1): pp. 1-21.
Gershoff, T. and Font, A. (2016). Corporal punishment in U.S. Public Schools: Prevalence, Disparities in Use, and Status in State and Federal Policy., from http://WWW.ants.org.au.Retrieved12 March 2019.

Navarro, W., Iglesias, L. and Torres, 0. (2015). Study of anew management element for universities: Satisfaction with the offered courses in Armenian, 2(1): PP. 25-30.

\section{JNSBU}


ادراك طلاب ومعلمي التمريض تجاه حقوق طلاب التمريض وعلاقتها برضاء طلاب التمريض نعيمة علي جودة احمد ـرضا عبد الفتاح ابو جاد - ابتسام سعيد احمد عبد الرحمن

أصبحت حقوق الطلاب جزءًا مهمًا من التعليم الحديث نظرًا لأنه عندما يعرف طلاب التمريض حقوقهم

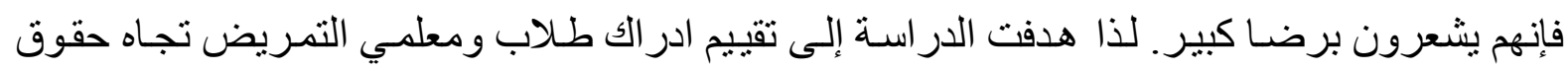

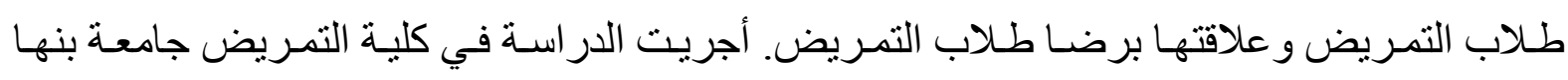

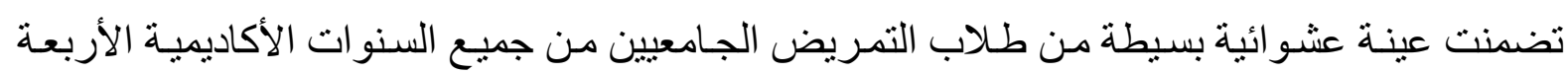

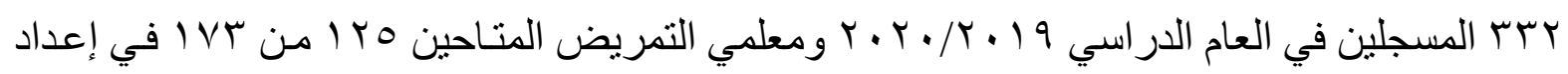

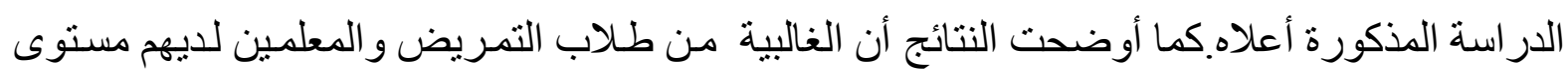

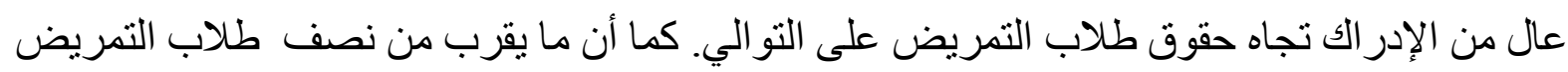

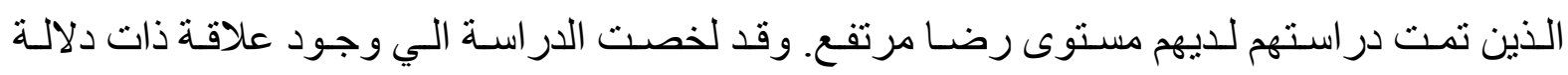

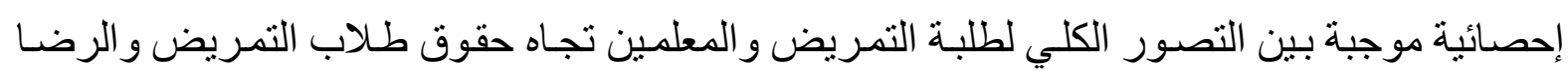
الكلي لطلبة التمريض. كما اوصت الدر اسه بنشر حقوق الطلاب في مو اقع متاحة لجميع الطلاب ونشر ها على مو اقع أعضاء هيئة التدريس. 